\title{
Prognostic value of YKL-40 in solid tumors: a meta-analysis of 41 cohort studies
}

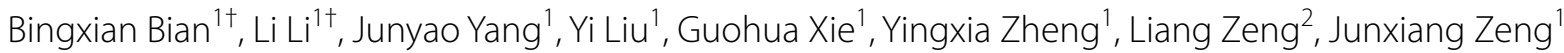 \\ and Lisong Shen ${ }^{1 *}$ (D)
}

\begin{abstract}
Background: Serum/plasma YKL-40 can be a useful index that is associated with tumor development. However, the prognostic value of serum/plasma YKL-40 in patients with solid tumors is still unclear. We aimed to utilize the existing literature to investigate the prognostic value of serum/plasma YKL-40 in solid tumors.

Methods: An extensive literature search for relevant studies was conducted with the Embase, Medline and Web of Science databases. The effect on survival was measured with the hazard ratio (HR). Then, pooled HRs and 95\% confidence intervals $(\mathrm{Cls})$ were calculated using the random and fixed-effects models according to the heterogeneity of the included studies.

Results: This meta-analysis was based on 41 publications and comprised a total of 7762 patients with solid tumors. The pooled HR showed that elevated serum/plasma YKL-40 was significantly associated with poor OS $(\mathrm{HR}, 1.44 ; 95 \% \mathrm{Cl}$ 1.33-1.56). We also found that elevated serum/plasma YKL-40 had significant prognostic effects on OS in various cancer subgroups such as gastrointestinal tumors ( $H R, 1.37 ; 95 \% \mathrm{Cl} 1.18-1.58)$, ovarian cancer ( $\mathrm{HR}, 2.27 ; 95 \% \mathrm{Cl} 1.69-3.06)$, melanoma ( $\mathrm{HR}, 1.77 ; 95 \% \mathrm{Cl} 1.18-2.67)$, lung cancer ( $\mathrm{HR}, 1.73 ; 95 \% \mathrm{Cl} 1.35-2.23)$, urologic neoplasms ( $\mathrm{HR}, 1.61 ; 95 \%$ $\mathrm{Cl} 1.08-2.40)$ and glioblastoma ( $\mathrm{HR}, 1.23 ; 95 \% \mathrm{Cl} 1.07-1.42)$; in contrast, the prognostic effect of serum/plasma YKL-40 was not statistically significant in breast cancer ( $\mathrm{HR}, 1.07 ; 95 \% \mathrm{Cl} 0.98-1.17)$.
\end{abstract}

Conclusions: The available evidence supports the hypothesis that elevated serum/plasma YKL-40 is associated with poor survival in patients with solid tumors and that serum/plasma YKL-40 may serve as a novel prognostic biomarker.

Keywords: Prognostic value, YKL-40, Solid tumors, Meta-analysis, Overall survival

\section{Background}

There were an estimated 18.1 million new cancer cases and 9.6 million cancer deaths in 2018, and cancer is expected to rank as the leading cause of death [1]. In this setting, prognostic indicators in patients with cancer are crucial. The tumor-node-metastasis (TNM) stage is considered the prognostic indicator most strongly associated with survival. However, for patients with the same stages, while some patients have a good prognosis, and others have a poor prognosis; thus, clinical tumor staging

\footnotetext{
${ }^{*}$ Correspondence: lisongshen@hotmail.com;

shenlisong@xinhuamed.com.cn

${ }^{\dagger}$ Bingxian Bian and Li Li contributed equally to this work

1 Department of Clinical Laboratory, Xin Hua Hospital, Shanghai Jiao Tong

University School of Medicine, Shanghai, China

Full list of author information is available at the end of the article
}

alone cannot predict patient prognosis. Therefore, additional indicators that can be used to predict prognosis are required.

YKL-40 is a mammalian member of a chitinase protein family but contains an enzymatically inactive property [2], and it is also known as human cartilage glycoprotein-39 (hCGP-39) and chitinase-3-like-1 protein (CHI3L1). YKL-40 is secreted by a variety of cells including monocytes, neutrophils, macrophages, chondrocytes, synovial cells, and tumor cells [3]. The clear expression of YKL-40 has been reported in cancer cells $[4,5]$. The exact biological functions of YKL-40 in cancer cells are still being studied. It is suggested that this protein plays a role in inflammation, stimulation of angiogenesis and regulation of extracellular tissue remodeling and thus, the expression of YKL-40 is increased in patients with 
cancer [6]. As a result, YKL-40 has been recognized as a new prognostic and predictive marker in many cancers. Moreover, YKL-40 plays a potential role in promoting tumor growth, which indicates that YKL-40 may serve as a therapeutic target. A mouse monoclonal anti-YKL-40 antibody ( $\mathrm{mAY}$ ) has shown to have therapeutic use in the treatment of tumor angiogenesis and metastasis [7]. The conjunctive therapy with $\mathrm{mAY}$ and ionizing irradiation (IR) synergistically inhibited tumor vascularization and progression in xenograft brain tumor models [8].

The first report on the prognostic value in solid tumors was a study of 41 patients with recurrent breast cancer by Johansen [9], which was followed by a series of studies that evaluated the prognostic value of serum/plasma YKL-40 in solid tumors, such as gastrointestinal tumors, ovarian cancer, melanoma, lung cancer, urologic neoplasms, glioblastoma, breast cancer, squamous cell carcinoma of the head and neck and so on. While some studies have demonstrated that serum/plasma YKL-40 has predictive and prognostic value in patients with cancer, some other studies have presented negative results. Therefore, the prognostic properties of serum/plasma YKL-40 in solid tumors remain controversial. Several meta-analyses investigated the prognostic value in certain cancers, such as glioblastoma and breast cancer [10, 11]. However, there has been no systematic analysis to quantify the existing data in solid tumors wholly. Therefore, in view of the conflicting results from previous studies, we utilized the existing literature to investigate the issue of the prognostic value of serum/plasma YKL-40 in solid tumors.

\section{Methods}

\section{Search strategy}

We conducted an extensive literature search for relevant studies from the Embase (from 1974 to March 08, 2019), Medline (from 1966 to March 08, 2019) and Web of Science databases (from 1985 to March 08, 2019). The search strategy included the following keywords: "YKL40”, “YKL40”, “CHI3L1”, "chitinase-3-like-1”, “GP-39”, "glycoprotein-39", “CGP-39”, "cartilage glycoprotein-39”, "hCGP-39", "human cartilage glycoprotein-39", "tumor", "neoplasm" and "cancer". Reports in English were eligible for inclusion. Furthermore, we manually reviewed the relevant articles to implement our search.

\section{Selection criteria and quality assessment}

Studies were included in the meta-analysis according to the following criteria: (1) patients with a diagnosis of solid tumor that was confirmed through histopathologic examinations; (2) sufficient data were provided to determine an estimate of the hazard ratio (HR) for OS and disease-free survival (DFS)/progression-free survival (PFS);
(3) more than 30 patients were enrolled in each study; and (4) cohort studies published in English. When the same patient population was used in multiple publications, only the latest was included in the meta-analysis. Reviews and comments were excluded.

Two investigators independently assessed the quality of the eligible studies. The Newcastle-Ottawa Scale (NOS) was used to assess study quality. The NOS is based on three parameters of quality: selection ( $0-4$ points), comparability ( $0-2$ points), and outcome assessment ( $0-3$ points). The scores ranged from zero points (worst) to nine points (best). Disagreements on the quality assessment were resolved by discussion. We also conducted sensitivity analyses to assess the stability of the results.

\section{Data extraction}

We extracted the following information from each study: author's name, publication year, patients' country, cancer type, number of patients, tumor stage, metastasis status, treatment methods, YKL-40 cutoff value, specimen type, and HR with $95 \%$ CI for DFS, PFS and OS. If the HRs and $95 \%$ CIs were not directly collected from the original article, they were calculated by the method of Parmar et al. [12].

\section{Statistical analysis}

The pooled HR or odds ratio (OR) was initially calculated by a fixed effect model [13]. If the $\mathrm{I}^{2}$ statistic was more than $30 \%$ or the fixed effects $\mathrm{P}$ value for the $\mathrm{I}^{2}$ statistic was less than 0.10 , indicating significant heterogeneity across studies, then a random effect model was applied to calculate the pooled HR or OR [14]. To explore the potential causes of heterogeneity, subgroup analyses and meta-regression analyses were conducted (HR was considered to be associated with covariates when the $\mathrm{P}$ value was less than 0.05 ). To evaluate the stability of the results, we conducted a sensitivity analysis by omitting each study in turn. The scope of this analysis was to evaluate the influence of a single study on the overall outcome. To investigate publication bias in the literature, we performed a visual inspection of the funnel plot symmetry and Begg's regression and Egger's linear regression tests $(\mathrm{P}<0.05$ was statistically significant $)[15,16]$. The nonparametric trim-and-fill method was performed to further assess the potential effect of publication bias [17]. All statistical analyses were performed using the Meta package in R software (version 3.5.1, The R Project for Statistical Computing).

\section{Results}

Study selection procedure

The flowchart of the study selection process is shown in Fig. 1. The literature search yielded a total of 1440 


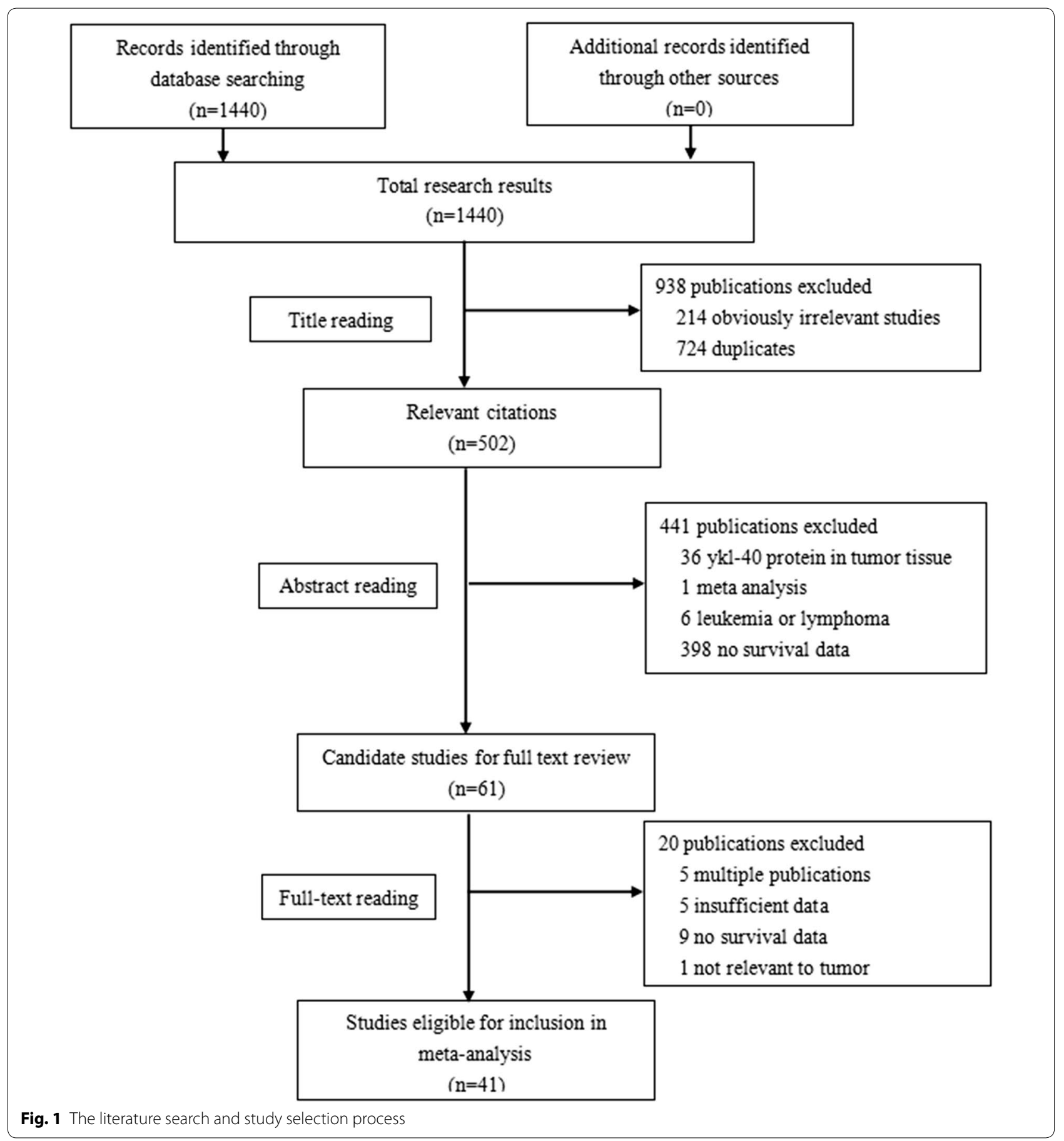

records. Of these articles, 502 studies were retrieved for detailed evaluation. In total, 461 studies were further excluded because of there was YKL-40 protein in the tumor tissue, the study was meta-analysis, the study involved leukemia or lymphoma, there were multiple publications, there was insufficient data, there was no survival data or the data was not relevant to tumor tissues. Finally, 41 articles $[9,18-57]$ met the selection criteria after reviewing the abstracts or full texts.

\section{Characteristics of identified studies}

The characteristics of the eligible studies are summarized in Tables 1 and 2. The sample size in each study ranged from 37 to 1432 patients, and a total of 7762 patients 
Table 1 Main characteristics of the eligible studies

\begin{tabular}{|c|c|c|c|c|c|c|}
\hline Study & Patients' country & No. of patients & Tumor stage $^{a}$ & Treatment methods & Cutoff value & Specimen type \\
\hline \multicolumn{7}{|l|}{ Breast cancer } \\
\hline Johansen 1995 [9] & Denmark & 41 & - & Chemotherapy & $207 \mu \mathrm{g} / \mathrm{L}$ & Serum \\
\hline Jensen 2003 [21] & Denmark & 100 & $\begin{array}{l}\text { Metastatic disease } \\
\quad(100)\end{array}$ & Chemotherapy & $168 \mu \mathrm{g} / \mathrm{L}$ & Serum \\
\hline Johansen 2003 [22] & England & 271 & - & $\begin{array}{l}\text { Surgery and } \\
\text { chemotherapy and } \\
\text { radiotherapy }\end{array}$ & - & Serum \\
\hline Yamac 2008 [29] & Turkey & 45 & $|-|||(62.2)$ & $\begin{array}{l}\text { Surgery and chemo- } \\
\text { therapy }\end{array}$ & - & Serum \\
\hline Wang 2012 [38] & China & 120 & TNM I-III (23.3) & Surgery & - & Serum \\
\hline \multicolumn{7}{|l|}{ Gastrointestinal tumors } \\
\hline Cintin 1999 [18] & Denmark & 603 & $\begin{array}{l}\text { Dukes'staging A-D } \\
\text { (53.4) }\end{array}$ & Surgery & $247 \mu \mathrm{g} / \mathrm{L}$ & Serum \\
\hline Chang 2009 [30] & America & 52 & $\|-I I I(-)$ & $\begin{array}{l}\text { Chemotherapy and } \\
\text { radiotherapy }\end{array}$ & Continuous variable & Plasma \\
\hline Zhu 2012 [39] & China & 212 & - & Chemoembolization & $106 \mu \mathrm{g} / \mathrm{L}$ & Serum \\
\hline Zhu 2012 [40] & China & 158 & TNM I-IV (38.0) & Surgery & Continuous variable & Serum \\
\hline \multirow[t]{2}{*}{ Schultz 2013 [41] } & \multirow{2}{*}{$\begin{array}{l}\text { Denmark and Ger- } \\
\text { many }\end{array}$} & 103 & \multirow[t]{2}{*}{-} & \multirow{2}{*}{$\begin{array}{l}\text { Surgery; chemother- } \\
\text { apy (not undergo- } \\
\text { ing surgery) }\end{array}$} & \multirow[t]{2}{*}{$116 \mu \mathrm{g} / \mathrm{L}$} & \multirow[t]{2}{*}{ Plasma } \\
\hline & & 370 & & & & \\
\hline Liu 2014 [43] & China & 86 & UICC I-IV (44.2) & $\begin{array}{l}\text { Surgery and chemo- } \\
\text { therapy }\end{array}$ & $216 \mu \mathrm{g} / \mathrm{L}$ & Serum \\
\hline Tarpgaard 2014 [44] & 32 Nordic centers & 510 & $\begin{array}{l}\text { Metastatic disease } \\
\quad(100)\end{array}$ & Chemotherapy & Continuous variable & Plasma \\
\hline Jensen 2016 [47] & Denmark & 162 & $\begin{array}{l}\text { Metastatic disease } \\
\quad(100)\end{array}$ & $\begin{array}{l}\text { Cetuximab and } \\
\text { irinotecan }\end{array}$ & Continuous variable & Plasma \\
\hline $\begin{array}{l}\text { Thongsom } 2016 \\
\text { [50] }\end{array}$ & Thailand & 57 & TNM I-IV (78.9) & Surgery & $100.7 \mu \mathrm{g} / \mathrm{L}$ & Plasma \\
\hline Gramkow 2017 [52] & Finland & 457 & $\begin{array}{l}\text { Metastatic disease } \\
(100)\end{array}$ & Liver resection & - & Serum \\
\hline Fuksiewicz 2018 [55] & Poland & 83 & - & Surgery & $44.6 \mu \mathrm{g} / \mathrm{L}$ & Serum \\
\hline \multicolumn{7}{|l|}{ Ovarian cancer } \\
\hline Dehn 2003 [19] & Denmark & 73 & I-IV (75.3) & Chemotherapy & $160 \mu \mathrm{g} / \mathrm{L}$ & Plasma \\
\hline Høgdall 2003 [20] & Denmark & 47 & $\|(100)$ & Surgery & $130 \mu \mathrm{g} / \mathrm{L}$ & Plasma \\
\hline Høgdall 2009 [31] & Denmark & 76 & I-IV (72.4) & $\begin{array}{l}\text { Surgery and chemo- } \\
\text { therapy }\end{array}$ & - & Plasma \\
\hline Boisen 2016 [49] & Denmark & 140 & FIGO I-IV (82.1) & Bevacizumab & - & Plasma \\
\hline \multicolumn{7}{|l|}{ Lung cancer } \\
\hline Johansen 2004 [23] & Denmark & 131 & $\begin{array}{l}\text { Limited and } \\
\text { extended disease } \\
(55.0)\end{array}$ & Chemotherapy & - & Serum \\
\hline Choi 2010 [34] & Korea & 39 & IIIB-IV (100) & Chemotherapy & $165 \mu \mathrm{g} / \mathrm{L}$ & Serum \\
\hline Thöm 2010 [35] & Germany & 189 & III-IV (100) & Chemotherapy & $209 \mu \mathrm{g} / \mathrm{L}$ & Serum \\
\hline Xu 2014 [46] & China & 120 & $\begin{array}{l}\text { Limited and } \\
\text { extended disease } \\
(41.7)\end{array}$ & Chemotherapy & $65.7 \mu \mathrm{g} / \mathrm{L}$ & Serum \\
\hline Matsuo 2019 [57] & Japan & 50 & III-IV (100) & Anti-PD-1 inhibitor & - & Plasma \\
\hline \multicolumn{7}{|l|}{ Urologic neoplasms } \\
\hline Brasso 2006 [24] & Denmark & 152 & $\begin{array}{l}\text { Metastatic disease } \\
(100)\end{array}$ & Endocrine therapy & $104 \mu \mathrm{g} / \mathrm{L}$ & Serum \\
\hline Johansen 2007 [27] & Denmark & 102 & - & $\begin{array}{l}\text { Total androgen abla- } \\
\text { tion or parenteral } \\
\text { estrogen }\end{array}$ & Continuous variable & Serum \\
\hline $\begin{array}{l}\text { Tschirdewahn } 2014 \\
\text { [45] }\end{array}$ & Germany & 101 & T stage $T_{a}-T_{4}(45.5)$ & Surgery & $90 \mu \mathrm{g} / \mathrm{L}$ & Serum \\
\hline
\end{tabular}


Table 1 (continued)

\begin{tabular}{|c|c|c|c|c|c|c|}
\hline Study & Patients' country & No. of patients & Tumor stage $^{a}$ & Treatment methods & Cutoff value & Specimen type \\
\hline Vom Dorp 2016 [48] & Germany & 152 & Stage pT1-T4 (40.1) & Surgery & $185 \mu \mathrm{g} / \mathrm{L}$ & Serum \\
\hline Väänänen 2017 [54] & Finland & 82 & $\begin{array}{l}\text { Metastatic and non- } \\
\text { metastatic disease } \\
(25.6)\end{array}$ & Surgery & $120 \mu \mathrm{g} / \mathrm{L}$ & Serum \\
\hline Darr 2018 [56] & Germany & 109 & $\begin{array}{l}\text { Metastatic dis- } \\
\text { ease(100) }\end{array}$ & Chemotherapy & $160 \mu \mathrm{g} / \mathrm{L}$ & Serum \\
\hline \multicolumn{7}{|l|}{ Melanoma } \\
\hline Schmidt 2006 [25] & Denmark & 225 & $|-| \mid(0)$ & Surgery & $124 \mu \mathrm{g} / \mathrm{L}$ & Serum \\
\hline Schmidt 2006 [26] & Denmark & 110 & IV (100) & $\begin{array}{l}\text { Chemotherapy and } \\
\text { immunotherapy }\end{array}$ & $124 \mu \mathrm{g} / \mathrm{L}$ & Serum \\
\hline Krogh 2016 [51] & Europe & 299 & Stage IIB and III (-) & Untreated & Continuous variable & Serum \\
\hline Erturk 2017 [53] & Turkey & 112 & - & $\begin{array}{l}\text { chemotherapy and } \\
\text { radiotherapy and } \\
\text { immunotherapy }\end{array}$ & $174.88 \mu \mathrm{gL}$ & Serum \\
\hline \multicolumn{7}{|c|}{ Squamous cell carcinoma of the head and neck } \\
\hline Roslind 2008 [28] & Denmark & 144 & I-IV (55.6) & Radiotherapy & - & Serum \\
\hline \multicolumn{7}{|l|}{ Multiple tumors } \\
\hline Johansen 2009 [32] & Denmark & 1432 & $\begin{array}{l}\text { Localized disease and } \\
\text { metastatic disease } \\
(40.8)\end{array}$ & - & - & Plasma \\
\hline \multicolumn{7}{|c|}{ Cervical adenocarcinoma } \\
\hline $\begin{array}{l}\text { Mitsuhashi } 2009 \\
\text { [33] }\end{array}$ & Japan & 37 & I-IV (29.7) & $\begin{array}{l}\text { Surgery and chemo- } \\
\text { radiation }\end{array}$ & $130 \mu \mathrm{g} / \mathrm{L}$ & Serum \\
\hline \multicolumn{7}{|l|}{ Glioblastoma } \\
\hline Iwamoto 2011 [36] & America & 141 & - & Surgery & $98 \mu \mathrm{g} / \mathrm{L}$ & Serum \\
\hline Bernardi 2012 [37] & Italy & 60 & $\begin{array}{l}\text { Astrocytoma } \\
\text { Grade IV (100) }\end{array}$ & $\begin{array}{l}\text { Surgery and irradia- } \\
\text { tion and chemo- } \\
\text { therapy }\end{array}$ & - & Serum \\
\hline Gállego 2014 [42] & France & 111 & - & Surgery & $60 \mu \mathrm{g} / \mathrm{L}$ & Plasma \\
\hline
\end{tabular}

- not reported

a Tumor stage and proportion of advanced stage(\%)

were included in the meta-analysis. These studies were published from 1995 and 2019. 32 studies were from Caucasian countries $[9,18-32,35-37,41,42,44,45$, 47-49, 51-56], and the other 9 studies were from Asian countries [33, 34, 38-40, 43, 46, 50, 57]. The proportion of stage IV(D) or stage III(C) disease and the proportion of metastatic or extended disease were used as the proportion of advanced stage disease in 20 studies [18-20, $25,26,28,29,31,33-35,37,38,40,43,45,48-50,57]$ and 10 studies [21, 23, 24, 32, 44, 46, 47, 52, 54, 56], respectively. The proportion of advanced stage disease was not reported in the other 11 studies [9, 22, 27, 30, 36, 39, 41, $42,51,53,55]$. Johansen et al. [27] investigated the midtherapy value of serum/plasma YKL-40, and Bernardi et al. [37] investigated the value of the serum/plasma YKL-40 ratio [(1 week value-baseline value)/baseline value]. The other studys investigated the baseline value of serum/plasma YKL-40 in solid tumors. The cutoff value of serum/plasma YKL-40 ranged from 44.6 to $247 \mu \mathrm{g} / \mathrm{L}$ in 24 studies $[9,18-21,24-26,33-36,39,41-43,45,46$,
48, 50, 53-56]. In total, 6 studies [27, 30, 40, 44, 47, 51] analyzed serum/plasma YKL-40 as a continuous variable, and the cutoff value was not reported in 11 studies [22, $23,28,29,31,32,37,38,49,52,57]$. A total of 39 studies $[18-54,56,57]$ reported HRs with $95 \%$ CIs for OS or DFS/PFS directly. The HR with a $95 \%$ CI for OS or DFS/ PFS was estimated from Kaplan-Meier curves in the other 2 studies $[9,55]$. The quality assessment of the trials is shown in Table 2.

\section{Effect of the value of serum/plasma YKL-40 on OS in solid tumors}

The HRs for OS were available in 38 studies $[9,18-32$, 34-42, 44-56], and 2 HRs were extracted from 2 studies each because 2 cohorts were used in these studies. The forest plot of all studies is provided in Fig. 2. As heterogeneity among studies clearly existed $\left(\mathrm{P}<0.01, \mathrm{I}^{2}=82 \%\right)$, a random-effects model was applied. The pooled HR showed that elevated serum/plasma YKL-40 was 
Table 2 Main results

\begin{tabular}{|c|c|c|c|c|}
\hline Author & Outcome & HR & $95 \% \mathrm{Cl}$ & NOS score \\
\hline \multicolumn{5}{|l|}{ Breast cancer } \\
\hline Johansen 1995 & OS & 2.2 & $0.83-5.81$ & 7 \\
\hline \multirow[t]{2}{*}{ Jensen 2003} & OS & 2.57 & $1.6-4.1$ & 9 \\
\hline & PFS & 1.96 & $1.2-3.1$ & \\
\hline Johansen 2003 & OS & 1.77 & $1.03-3.06$ & 8 \\
\hline Yamac 2008 & OS & 1.004 & $1.00-1.07$ & 7 \\
\hline \multirow[t]{2}{*}{ Wang 2012} & OS & 1.04 & $1.02-1.06$ & 7 \\
\hline & DFS & 1.02 & $1.00-1.03$ & \\
\hline \multicolumn{5}{|c|}{ Gastrointestinal tumors } \\
\hline Cintin 1999 & OS & 1.4 & $1.1-1.8$ & 8 \\
\hline Chang 2009 & OS & 0.99 & $0.76-1.28$ & 7 \\
\hline Zhu 2012 & OS & 1.809 & $1.259-2.601$ & 8 \\
\hline Zhu 2012 & OS & 2.188 & $1.237-3.870$ & 8 \\
\hline \multirow[t]{2}{*}{ Schultz 2013} & OS & 0.69 & $0.36-1.33$ & 7 \\
\hline & OS & 1.30 & $1.03-1.64$ & \\
\hline Liu 2014 & PFS & 1.653 & $1.123-2.416$ & 7 \\
\hline \multirow{2}{*}{ Tarpgaard 2014} & OS & 1.17 & $1.05-1.30$ & 7 \\
\hline & PFS & 1.00 & $0.91-1.09$ & \\
\hline \multirow[t]{2}{*}{ Jensen 2016} & OS & 1.53 & $1.1-2.13$ & 6 \\
\hline & OS & 2.89 & $1.84-4.53$ & \\
\hline Thongsom 2016 & OS & 1.642 & $0.780-3.455$ & 7 \\
\hline Gramkow 2017 & OS & 1.19 & $1.05-1.34$ & 6 \\
\hline \multirow[t]{2}{*}{ Fuksiewicz 2018} & OS & 1.5 & $0.36-6.2$ & 7 \\
\hline & DFS & 0.93 & $0.39-2.24$ & \\
\hline \multicolumn{5}{|l|}{ Ovarian cancer } \\
\hline Dehn 2003 & OS & 2.27 & $1.27-4.06$ & 7 \\
\hline Høgdall 2003 & OS & 3.95 & $1.52-10.273$ & 7 \\
\hline Høgdall 2009 & OS & 2.13 & $1.40-3.25$ & 7 \\
\hline \multirow[t]{2}{*}{ Boisen 2016} & OS & 1.97 & $0.90-4.32$ & 7 \\
\hline & PFS & 2.91 & $1.07-7.92$ & \\
\hline \multicolumn{5}{|l|}{ Lung cancer } \\
\hline Johansen 2004 & OS & 1.96 & $1.13-3.40$ & 7 \\
\hline Choi 2010 & OS & 3.6 & $1.25-10.39$ & 7 \\
\hline Thöm 2010 & OS & 1.48 & $1.04-2.10$ & 8 \\
\hline \multirow[t]{2}{*}{ Xu 2014} & OS & 1.84 & $1.08-3.15$ & 7 \\
\hline & PFS & 1.12 & $1.01-1.23$ & \\
\hline Matsuo 2019 & PFS & 1.119 & $0.992-1.262$ & 7 \\
\hline \multicolumn{5}{|l|}{ Urologic neoplasms } \\
\hline Brasso 2006 & OS & 1.3 & $1.0-1.7$ & 8 \\
\hline Johansen 2007 & OS & 1.0 & $0.7-1.3$ & 7 \\
\hline Tschirdewahn 2014 & OS & 1.837 & $1.039-3.375$ & 8 \\
\hline Vom Dorp 2016 & OS & 3.854 & $2.222-6.686$ & 8 \\
\hline Väänänen 2017 & OS & 3.19 & $1.38-7.36$ & 7 \\
\hline Darr 2018 & OS & 0.933 & $0.621-1.401$ & 6 \\
\hline \multicolumn{5}{|l|}{ Melanoma } \\
\hline Schmidt 2006 & OS & 3.6 & $1.7-7.7$ & 9 \\
\hline Schmidt 2006 & OS & 1.9 & $1.2-2.8$ & 9 \\
\hline Krogh 2016 & OS & 1.28 & $1.05-1.57$ & 8 \\
\hline Erturk 2017 & OS & 1.568 & $0.580-3.051$ & 7 \\
\hline
\end{tabular}

Table 2 (continued)

\begin{tabular}{|c|c|c|c|c|}
\hline Author & Outcome & HR & $95 \% \mathrm{Cl}$ & NOS score \\
\hline \multicolumn{5}{|c|}{ Squamous cell carcinoma of the head and neck } \\
\hline Roslind 2008 & OS & 2.16 & $1.39-3.35$ & 9 \\
\hline \multicolumn{5}{|l|}{ Multiple tumors } \\
\hline Johansen 2009 & OS & 1.8 & $1.3-2.5$ & 9 \\
\hline \multicolumn{5}{|c|}{ Cervical adenocarcinoma } \\
\hline Mitsuhashi 2009 & DFS & 11 & $1.29-97$ & 8 \\
\hline \multicolumn{5}{|l|}{ Glioblastoma } \\
\hline Iwamoto 2011 & OS & 1.2 & $1.0-1.4$ & 8 \\
\hline Bernardi 2012 & OS & 1.97 & $1.03-3.8$ & 6 \\
\hline \multirow[t]{2}{*}{ Gállego 2014} & OS & 1.21 & $0.89-1.64$ & 7 \\
\hline & PFS & 1.09 & $0.83-1.42$ & \\
\hline
\end{tabular}

HR hazard ratio, $\mathrm{Cl}$ confidence interval, NOS Newcastle-Ottawa scale, OS overall survival, PFS progression-free survival, DFS disease-free survival

significantly associated with poor OS (HR, 1.44; 95\% CI $1.33-1.56)$.

To explore potential causes of heterogeneity, we performed meta-regression analyses using the following covariates: ethnicity, publication year, YKL-40 cutoff value, sample size, proportion of advanced stage disease, and specimen type, and treatment method(surgery vs. other treatment methods). The results indicated that ethnicity $(\mathrm{P}=0.5611$; Table 3$)$, publication year $(\mathrm{P}=0.4102)$, YKL-40 cutoff value $(\mathrm{P}=0.5199)$, sample size $(\mathrm{P}=0.3790)$, proportion of advanced stage disease $(\mathrm{P}=0.2221)$, specimen type $(\mathrm{P}=0.9164)$ and treatment method (0.7215) did not contribute to the cause of heterogeneity.

A visual inspection of the funnel plot revealed asymmetry. This was confirmed by Egger's test $(\mathrm{P}<0.01)$, although Begg's test did not indicate statistical significance $(P=0.244)$. For this reason, we performed a trim-and-fill analysis and found that 19 studies might be missing (Fig. 3). When these studies were published, the adjusted HR was 1.13 (95\% CI 1.05-1.22; P $<0.01$, $\mathrm{I}^{2}=85 \%$; Additional file 1: Figure S1), and the results continued to show a statistically significant association between serum/plasma YKL-40 and OS. The sensitivity analysis indicated that no individual studies significantly affected the overall outcome and demonstrated the stability of the results (Additional file 2: Figure S2).

\section{Effect of the value of serum/plasma YKL-40 on OS in gastrointestinal tumors}

A total of 10 studies comprising 2865 patients reported 12 HRs for OS in gastrointestinal tumors [18, 30, 3941, 44, 47, 50, 52, 55]. Overall, elevated serum/plasma YKL-40 was associated with poor OS (HR, 1.37; 95\% 


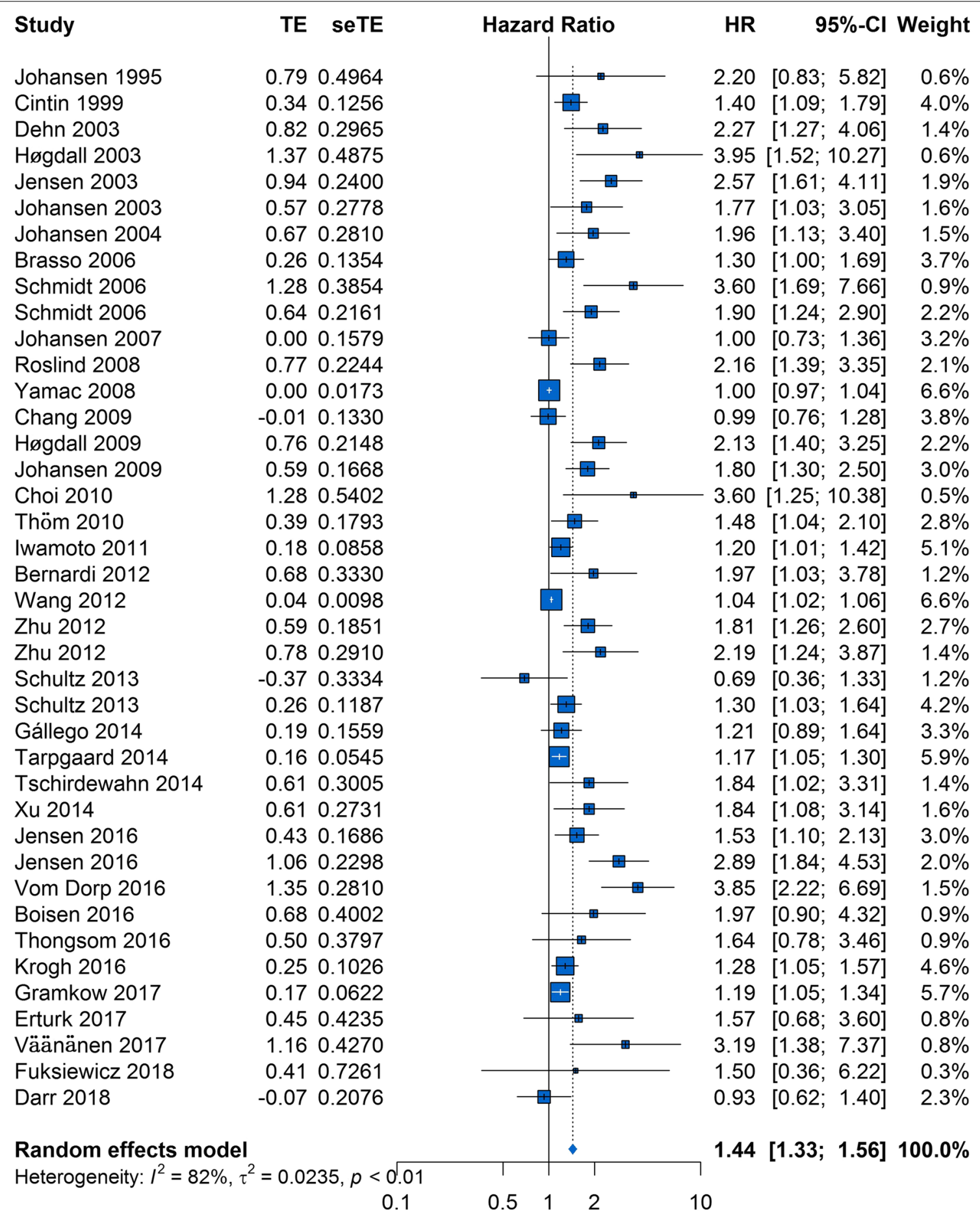

Fig. 2 Forest plot showing the meta-analysis of the hazard ratio estimates for overall survival in all patients

CI 1.18-1.58; Fig. 4). As heterogeneity existed among studies $\left(\mathrm{P}<0.01, \mathrm{I}^{2}=66 \%\right)$, a random-effects model was applied.

In the subgroup analysis based on ethnicity, there was a significant relationship between elevated serum/plasma
YKL-40 and poor OS in both the "Caucasian countries" subgroup and the "Asian countries" subgroup (HR, 1.28; 95\% CI 1.11-1.48 and HR, 1.87; 95\% CI 1.41-2.48, respectively; Additional file 3: Figure S3a). Statistical heterogeneity was significant in the "Caucasian countries" 
Table 3 Results of meta-regression analyses exploring causes of heterogeneity with overall survival in solid tumors

\begin{tabular}{ll}
\hline Covariates & $\begin{array}{l}\text { OS } \\
\text { Multivariate } \\
\text { analysis } \\
\text { P }\end{array}$ \\
\hline Ethnicity & 0.5611 \\
Publication year & 0.4102 \\
YKL-40 cutoff value & 0.5199 \\
Sample size & 0.3790 \\
Proportion of advanced stage & 0.2221 \\
Specimen type & 0.9164 \\
Treatment method & 0.7215 \\
\hline
\end{tabular}

OS overall survival

subgroup, whereas it was not significant in the "Asian countries" subgroup $\left(\mathrm{I}^{2}=66 \%, \mathrm{P}<0.01\right.$ and $\mathrm{I}^{2}=0 \%$, $\mathrm{P}=0.80$, respectively).

In addition, we investigated the prognostic role of serum/plasma YKL-40 with respect to OS for patients who received different treatment methods. Patients received surgery alone in some studies and other treatment methods in the other studies. There was a significant relationship between elevated serum/plasma YKL-40 and poor OS in both the "surgery" subgroup and the "other treatment methods" subgroup (HR, 1.31; 95\% CI 1.05-1.63 and HR, 1.43; 95\% CI 1.14-1.80, respectively; Additional file 3: Figure S3b). Statistical heterogeneity was significant in the "other treatment methods" subgroup, whereas it was not significant in the "surgery" subgroup $\left(\mathrm{I}^{2}=79 \%, \quad \mathrm{P}<0.01\right.$ and $\mathrm{I}^{2}=44 \%, \mathrm{P}=0.11$, respectively).

To explore potential causes of heterogeneity, we performed meta-regression analyses using the following covariates: ethnicity, publication year, YKL-40 cutoff value, sample size, proportion of advanced stage disease, specimen type, and treatment method. The results indicated that the only explanatory variable that influenced HR was ethnicity $(\mathrm{P}=0.0407$, Table 4$)$ and that publication year $(\mathrm{P}=0.5750)$, YKL-40 cutoff value $(\mathrm{P}=0.0908)$, sample size $(\mathrm{P}=0.6562)$, proportion of advanced stage disease $(P=0.4457)$, specimen type $(P=0.4700)$, and treatment method $(\mathrm{P}=0.6596)$ did not contribute to the cause of heterogeneity.

A visual inspection of the funnel plot did not reveal asymmetry (Additional file 4: Figure S4). This was confirmed by Egger's test $(\mathrm{P}=0.1129)$ and Begg's test $(\mathrm{P}=0.337)$. The sensitivity analysis indicated that no individual studies significantly affected the overall outcomes and demonstrated the stability of the results (Additional file 5: Figure S5).

\section{Effect of the value of serum/plasma YKL-40 on OS in other cancers}

As shown in Fig. 5, the prognostic effect of serum/plasma YKL-40 was highest in ovarian cancer (HR, 2.27; 95\% CI 1.69-3.06; $\mathrm{P}=0.68, \mathrm{I}^{2}=0 \%$; Fig. $6 \mathrm{a}$ ), followed by melanoma (HR, 1.77; 95\% CI 1.18-2.67; $\mathrm{P}=0.03, \mathrm{I}^{2}=65 \%$; Fig. 6b), lung cancer (HR, 1.73; 95\% CI 1.35-2.23; $\mathrm{P}=0.42, \mathrm{I}^{2}=0 \%$; Fig. 6c), urologic neoplasms (HR, 1.61; 95\% CI 1.08-2.40; $\mathrm{P}<0.01, \mathrm{I}^{2}=81 \%$; Fig. $6 \mathrm{~d}$ ) and glioblastoma (HR, 1.23; 95\% CI 1.07-1.42; $\mathrm{P}=0.35, \mathrm{I}^{2}=4 \%$;

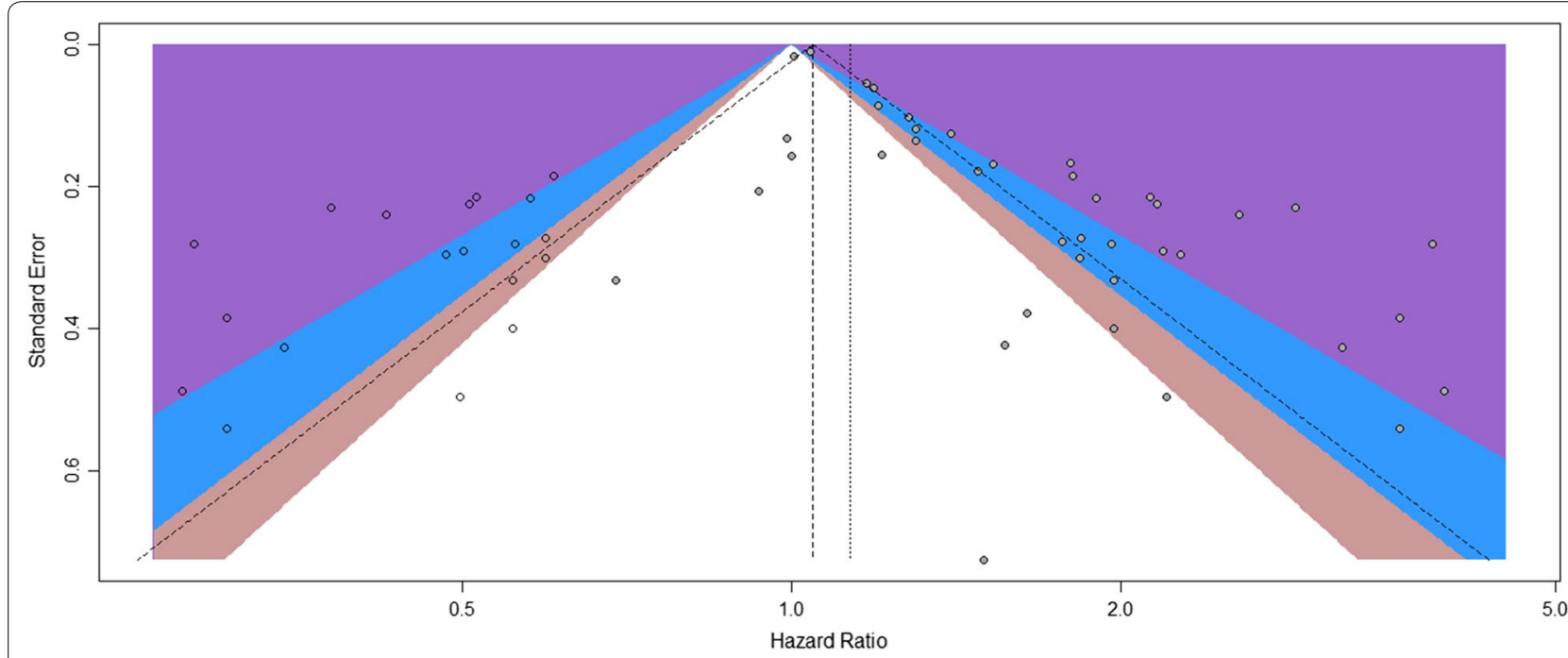

Fig. 3 Contour-enhanced funnel plot of the association between serum/plasma YKL-40 and overall survival in all patients. The hollow circles represent the missing studies that the trim-and-fill method identified 


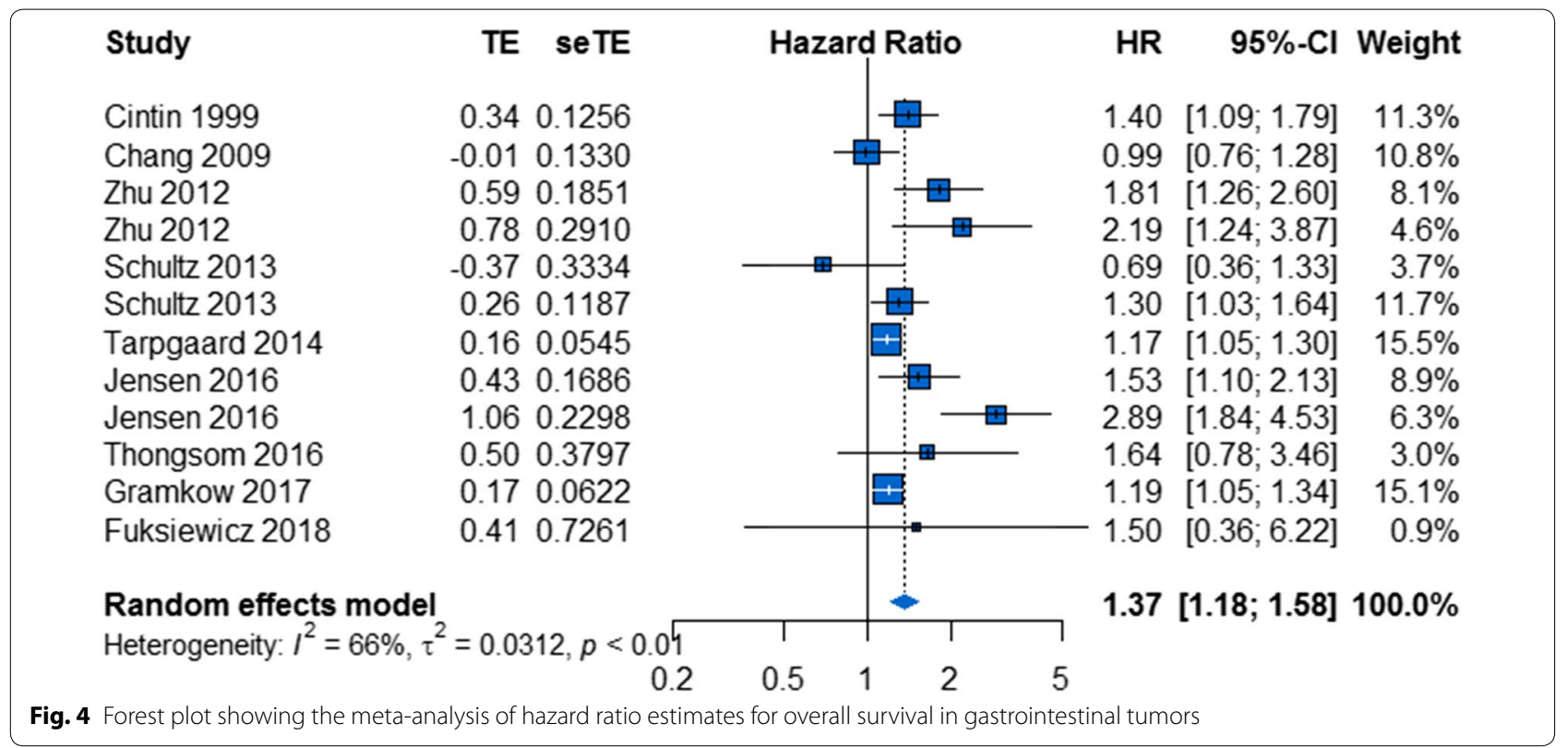

Table 4 Results of meta-regression analyses exploring causes of heterogeneity with overall survival in gastrointestinal tumor

\begin{tabular}{ll}
\hline Covariates & $\begin{array}{l}\text { OS } \\
\text { Univariate } \\
\text { analysis } \\
\text { P }\end{array}$ \\
\hline Ethnicity & 0.0407 \\
Publication year & 0.5750 \\
YKL-40 cutoff value & 0.0908 \\
Sample size & 0.6562 \\
Proportion of advanced stage & 0.4457 \\
Specimen type & 0.4700 \\
Treatment method & 0.6596 \\
\hline
\end{tabular}

OS overall survival

Fig. 6e); in contrast, the prognostic effect of serum/ plasma YKL-40 was not statistically significant in breast cancer (HR, 1.07; 95\% CI 0.98-1.17; $\mathrm{P}<0.01, \mathrm{I}^{2}=83 \%$; Fig. 6f).

\section{Effect of the value of serum/plasma YKL-40 on DFS/PFS in solid tumors}

In total, $10 \mathrm{HRs}$ for DFS/PFS were available in 10 studies $[21,33,38,42-44,46,49,55,57]$. The estimated pooled HR for these studies showed a high risk of disease progression in patients with elevated serum/plasma YKL40 (HR, 1.11; 95\% CI 1.02-1.22; Additional file 6: Figure S6). As heterogeneity existed among studies $(\mathrm{P}<0.01$, $\mathrm{I}^{2}=68 \%$ ), a random-effects model was applied.
To explore potential causes of heterogeneity, we performed meta-regression analyses using the following covariates: ethnicity, publication year, YKL-40 cutoff value, sample size, proportion of advanced stage disease, and specimen type and treatment method. The results indicated that the only explanatory variable that influenced HR was the YKL-40 cutoff value $(\mathrm{P}=0.0017$; Additional file 7: Table $\mathrm{S} 1)$ and that ethnicity $(\mathrm{P}=0.9445)$, publication year $(\mathrm{P}=0.6929)$, sample size $(\mathrm{P}=0.0538)$, proportion of advanced stage disease $(\mathrm{P}=0.8162)$, and specimen type $(\mathrm{P}=0.4427)$ and treatment method $(\mathrm{P}=0.3932)$ did not contribute to the cause of heterogeneity.

\section{YKL-40 and clinicopathological parameters}

Several studies investigated the associations between YKL-40 and clinicopathological parameters. Eight studies reported related data. Of these, 4 studies reported the association between YKL-40 and tumor stage (IIIIVvs.I-II, C-D vs. A-B or extended vs. limited); 3 studies reported the association between YKL-40 and metastasis status (lymph node or liver metastasis vs. no metastasis); and 1 study reported both. Pooled outcome from five studies demonstrated a strong association between YKL-40 and clinical stage(OR, 1.47; 95\% CI 1.02-2.12; Additional file 8: Figure S7a). Unfortunately, similar association was not observed between YKL-40 and metastasis status (OR, 2.14; 95\% CI 0.89-5.14; Additional file 8: Figure S7b) in 4 studies. 


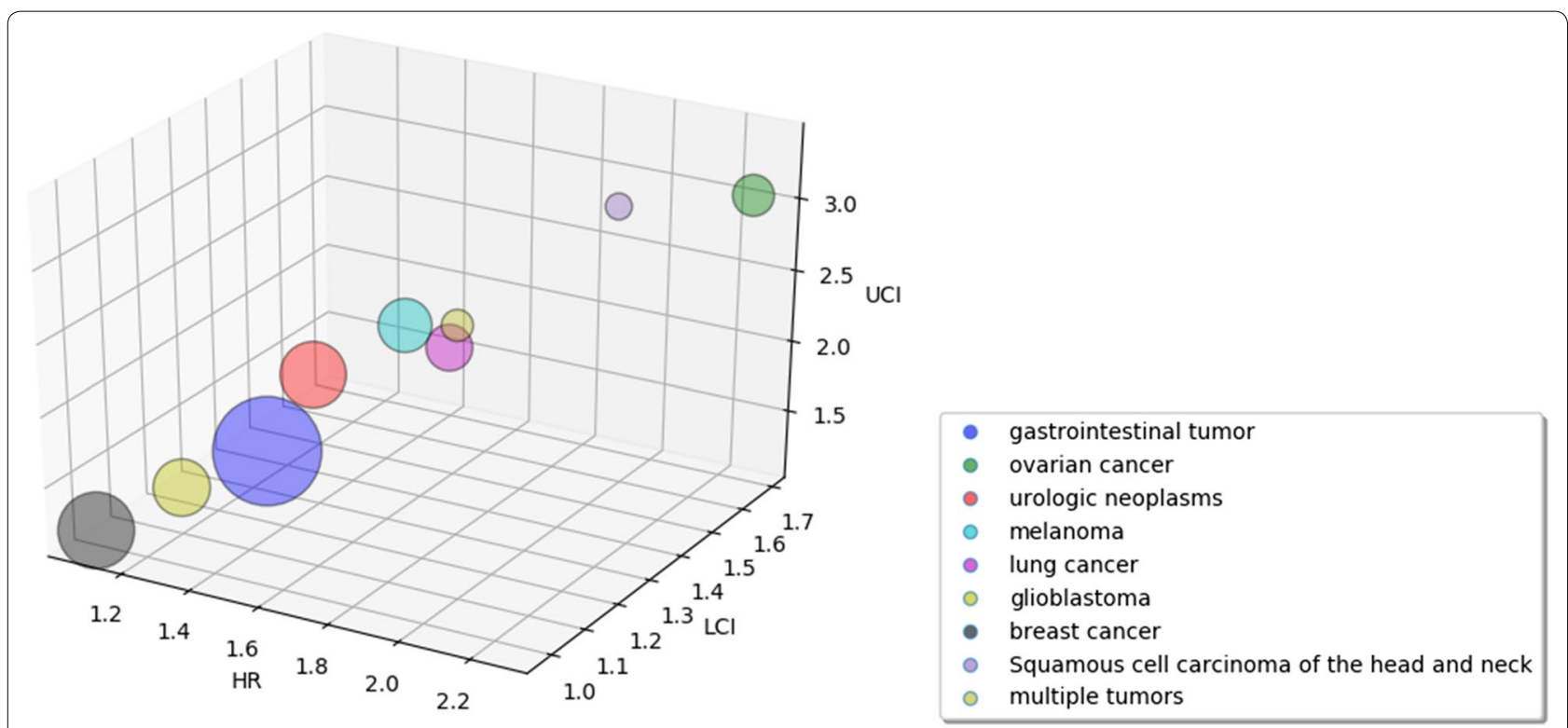

Fig. 5 Hazard ratios and 95\% confidence intervals by disease subgroups. The x-axis represents the hazard ratio for each subgroup, the $y$-axis represents the $\mathrm{LCl}$, and the z-axis represents the UCI. LCl lower confidence interval, UCl upper confidence interval

\section{Discussion}

YKL-40 has been suggested to have prognostic value in various cancers. Previous studies showed the prognostic value of serum/plasma YKL-40 in solid tumors was controversial and it was lack of high quality study. Here, we performed a meta-analysis of 41 studies comprising 7762 patients with solid tumors to evaluate the prognostic value of YKL-40. To our acknowledge, several meta-analyses investigated the prognostic value in certain cancers, such as glioblastoma and breast cancer [10, 11]. However, our study is the first systematic analysis to quantify the existing data in solid tumors wholly.

Reportedly, Jeet's study revealed that knockdown of YKL-40 in the bone metastatic C4-2B cells decreased both migration and invasion, whereas overexpression in less aggressive LNCaP cells rendered them more migratory and invasive [58]. Moreover, Ku's study showed that YKL-40 affected glioma cell invasion through regulation of MMP-2 expression, adhesion to ECM, cytoskeleton rearrangement and contractility [5]. In addition, YKL-40 significantly promoted the chemotaxis of macrophages and the angiogenesis accompanied by the increased secretion of IL- 8 and MCP-1 through the MAPK signaling pathway [4]. Based on these findings, YKL-40 was thought to be a prognostic and predictive marker in tumors. In our study, elevated serum/plasma YKL-40 was significantly associated with poor OS (HR, 1.44; 95\% CI 1.33-1.56), which meant serum/plasma YKL-40 could be a prognostic marker in solid tumors and confirmed the above point. Moreover, our meta-analysis also confirmed that YKL-40 was closely associated with clinical stage, which indicated that elevated YKL-40 may promote advanced stage because of its biology role, such as angiogenesis [6]. However, we failed to discover the similar result with regard to metastasis, which may be caused by the small sample size included.

We also found significant prognostic effects of elevated serum/plasma YKL-40 on OS among various cancer subgroups, such as gastrointestinal tumors, ovarian cancer, melanoma, lung cancer, urologic neoplasms and glioblastoma; in contrast, the prognostic effect of serum/plasma YKL-40 was not significant in breast cancer. Wan's study showed elevated YKL-40 expression was significantly associated with poor overall survival in breast cancer [11], and it seems that our results are not the same as its results. That is probably largely because of selection criteria. Unlike us, both the correlation between serum/plasma YKL-40 and prognosis and the correlation between YKL-40 in tissue and prognosis were chosen to study in Wan's study [11], and thus our 95\% CI of HR for the prognostic value of YKL-40 in breast cancer would be expanded because of the smaller sample size. To a large extent, it led to our negative result. In view of this, the prognostic value of serum/plasma YKL-40 in breast cancer still needs to be assessed through large studies.

Clinically, the expression of YKL-40 has been observed in serum/plasma and tissue. For example, several studies investigated the prognostic value of YKL-40 in tissue in various tumors, such as glioblastoma $[59,60]$ and breast cancer [61, 62]. However, some patients with tumors may not require surgeries and unnecessary tumor biopsies carry some risks for patients. Therefore, serum/plasma 
a

$\begin{array}{lllll}\text { Study } & \text { HE seTE Hazard Ratio } & 95 \%-\mathrm{Cl} \text { Weight }\end{array}$

$\begin{array}{lllllll}\text { Dehn } 2003 & 0.82 & 0.2965 & - & 2.27 & {[1.27 ; 4.06]} & 26.2 \%\end{array}$

Høgdall $2003 \quad 1.37 \quad 0.4875$

Høgdall $2009 \quad 0.76 \quad 0.2148$

$0.68 \quad 0.4002$

Boisen 2016

Fixed effect model

Heterogeneity: $I^{2}=0 \%, \tau^{2}=0, p=0.68$

b

Study

TE seTE

$\begin{array}{lll}0.5 & 1 & 2\end{array}$

Schmidt 2006

1.280 .3854

Schmidt 2006

0.640 .2161

Krogh 2016

0.250 .1026

Erturk 2017

$0.45 \quad 0.4235$

Random effects model

Heterogeneity: $I^{2}=65 \%, \tau^{2}=0.1036, p=0.03$

C

$\begin{array}{lllll}\text { Study } & \text { TE seTE } & \text { Hazard Ratio } & \text { HR } & 95 \%-\mathrm{Cl} \text { Weight }\end{array}$

Johansen $2004 \quad 0.670 .2810$

Choi $2010 \quad 1.280 .5402$

Thöm $2010 \quad 0.390 .1793$

Xu $2014 \quad 0610.2731$

Fixed effect model

Heterogeneity: $I^{2}=0 \%, \tau^{2}=0, p=0.42$

Hazard Ratio HR $\quad 95 \%-\mathrm{Cl}$ Weight

Study

TE seTE

Brasso 2006

Johansen 2007

Tschirdewahn 2014

Vom Dorp 2016

Väänänen 2017

0.260 .1354

0.000 .1579

0.610 .3005

1.350 .2810

Darr 2018

$1.16 \quad 0.4270$

$-0.070 .2076$

Random effects model

Heterogeneity: $I^{2}=81 \%, \tau^{2}=0.1896, p<0.01$

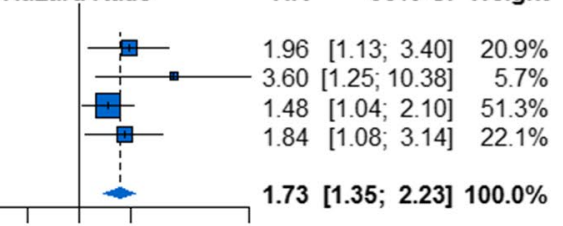

$\begin{array}{llll}0.5 & 1 & 2 & 10\end{array}$

.13 $[1.52,10.27$

$1.97[0.90 ; 4.32] 14.4 \%$

$2.27[1.69 ; 3.06] 100.0 \%$

$1.90 \quad[1.69 ; 7.66] \quad 17.3 \%$

$1.28[1.05 ; 1.57] \quad 38.2 \%$

$1.57[0.68 ; 3.60] \quad 15.4 \%$

$1.77[1.18 ; 2.67] 100.0 \%$

$\begin{array}{lrr}\text { Study } & \text { TE } & \text { seTE } \\ & & \\ \text { Iwamoto 2011 } & 0.18 & 0.0858 \\ \text { Bernardi 2012 } & 0.68 & 0.3330 \\ \text { Gállego 2014 } & 0.19 & 0.1559\end{array}$

Fixed effect model

Heterogeneity: $I^{2}=4 \%, \tau^{2}=0.0012, p=0.35$

HR $\quad 95 \%-\mathrm{Cl}$ Weight

Study

TE seTE

0.512

$\begin{array}{cc}\text { TE } & \text { SeTE } \\ & \\ 0.79 & 0.4964 \\ 0.94 & 0.2400 \\ 0.57 & 0.2778 \\ 0.00 & 0.0173 \\ 0.04 & 0.0098\end{array}$

Hazard Ratio

HR $\quad 95 \%-\mathrm{Cl}$ Weight

Johansen 1995

Jensen 2003

Johansen 2003

Yamac 2008

0.040 .0098

Random effects mode

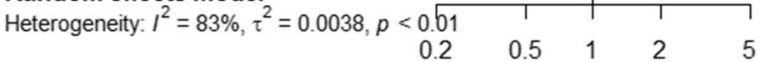

$2.20[0.83 ; 5.82] \quad 0.8 \%$

$2.57[1.61 ; 4.11] \quad 3.1 \%$

$1.77[1.03 ; 3.05] \quad 2.3 \%$

$1.00[0.97 ; 1.04] \quad 45.7 \%$

$1.04[1.02 ; 1.06] \quad 48.1 \%$

$1.07[0.98 ; 1.17] 100.0 \%$

Fig. 6 Forest plot showing the meta-analysis of hazard ratio estimates for overall survival in a ovarian cancer, $\mathbf{b}$ melanoma, c lung cancer, $\mathbf{d}$ urologic neoplasms, e glioblastoma, and $\mathbf{f}$ breast cancer 
YKL-40 is more promising. Moreover, a study of 10-year period in healthy subjects showed plasma had minimal intraindividual variability [63].

Plasma and serum YKL-40 levels were both used in our included studies. Certain tests may require a certain specimen for the measurement, but the meta-regression results showed that the specimen type did not influence the HR, which means that the prognostic value of YKL40 was not influenced by the specimen type.

Different YKL-40 cutoff values were used in our included studies. Although some studies used the 95\% percentile of the serum YKL-40 concentration in healthy controls, the selection criteria of some studies were still unclear. Although the YKL-40 cutoff value may influence the HR for DFS/PFS according to the meta-regression in solid tumors, it was unlikely to influence the overall prognostic value of YKL-40 in various cancers because YKL40 cutoff value did not influence the HR for OS according to the meta-regression in solid tumors. More large studies are needed to evaluate the optimal YKL-40 cutoff value for prognostic assessment in solid tumors.

Subgroup analysis by ethnicity in gastrointestinal tumors indicated that statistical heterogeneity was found in the "Caucasian countries" subgroup, whereas it was not significant in the "Asian countries" subgroup $\left(\mathrm{I}^{2}=66 \%, \mathrm{P}<0.01\right.$ and $\mathrm{I}^{2}=0 \%, \mathrm{P}=0.80$, respectively). We also found that ethnicity $(\mathrm{P}=0.0407)$ could influence $H R$ in the meta-regression. This result means that ethnicity was another potential source of heterogeneity, in part because of the low number of studies about Asian populations and discrepancies between studies. More large studies are needed to assess the prognostic value of YKL40 in gastrointestinal tumors in Asian populations.

In addition, the subgroup analysis by treatment method in gastrointestinal tumors suggested that the prognostic value of serum/plasma YKL-40 for OS was significant in both the "surgery" subgroup and the "other treatment methods" subgroup. However, it is difficult to determine whether the prognostic effect of YKL-40 was independent of treatment methods based on available studies. The reason for this drawback is that there was marked heterogeneity in the patients' response to different treatment regimens. Further studies are needed to evaluate the relevant prognostic factors.

The present study has several advantages. First, we performed a comprehensive and systematic search for relevant studies without limitations on the country of origin. Second, a meta-analysis with 8 included studies was performed to investigate the prognostic value of YKL-40 in glioblastoma by Qin et al. [10], and another meta-analysis with 10 included studies was performed to investigate the prognostic value of YKL-40 in breast cancer by Wan et al. [11] Both found that elevated YKL-40 was associated with poor prognosis. Our meta-analysis included 41 cohort studies and 7762 patients and thus is larger than the previous studies, which could lead to an increase in the statistical power and more precisely evaluate the prognostic value of YKL-40 in solid tumors. Third, the type of tumors was broadly defined, and the studies included gastrointestinal tumors, ovarian cancer, urologic neoplasms, melanoma, lung cancer, glioblastoma and breast cancer. Therefore, our meta-analysis performed a largescale investigation of the existing data in solid tumors wholly. Fourth, subgroup analyses and meta-regression analyses were conducted to explore the potential causes of heterogeneity such as ethnicity, publication year, YKL40 cutoff value, sample size, proportion of advanced stage disease, specimen type and treatment method; we found that the YKL-40 cutoff value and ethnicity may influence the HR according to the meta-regression.

There are limitations to this meta-analysis. First, we found publication bias, which indicated that fewer negative results were published than would be expected. Although we tried our best to conduct an extensive literary search for relevant studies, it is inevitable that some studies were missing. However, after performing a trimand-fill analysis, we found that even when the 19 missing studies were published, an elevated serum/plasma YKL40 was still associated with poor OS in solid tumors. Second, the number of studies was not sufficient for Asian populations. Third, our study is based on summarized data, and we did not obtain updated individual patient data, which may reduce the accuracy of the results. Fourth, significant heterogeneity existed among the studies. Although the YKL-40 cutoff value and ethnicity influenced HR in the meta-regression, different experimental designs, individual treatment regimens and lifestyles may also contribute to the heterogeneity. Therefore, further large multicenter prospective studies based on homogeneous populations should be conducted.

\section{Conclusion}

In conclusion, the available evidence supports the hypothesis that elevated serum/plasma YKL-40 is associated with poor survival in patients with solid tumors and that YKL-40 may serve as a novel prognostic biomarker. We also found significant prognostic effects of elevated serum/plasma YKL-40 on OS in various cancer subgroups such as gastrointestinal tumors, ovarian cancer, melanoma, lung cancer, urologic neoplasms and glioblastoma, whereas the prognostic effect of serum/ plasma YKL-40 was not statistically significant in breast cancer. Therefore, further large prospective studies using standardized unbiased methods still should be conducted to assess the prognostic effect of serum/ plasma YKL-40 in breast cancer. 


\section{Supplementary information}

Supplementary information accompanies this paper at https://doi. org/10.1186/s12935-019-0983-y.

Additional file 1: Figure S1. Forest plot showing the meta-analysis of hazard ratio estimates for overall survival in all patients after the trim-andfill method was applied.

Additional file 2: Figure S2. Sensitivity analysis for the pooled hazard ratios in overall survival in all patients. The analysis was conducted by estimating the average hazard ratio in the absence of each study.

Additional file 3: Figure S3. Forest plot showing the meta-analysis of hazard ratio estimates for overall survival in (a) the "Caucasian countries" subgroup and the "Asian countries" subgroup and (b) the "surgery" subgroup and "other treatment methods" subgroup.

Additional file 4: Figure S4. Contour-enhanced funnel plot of the association between serum/plasma YKL-40 and overall survival in gastrointestinal tumors.

Additional file 5: Figure S5. Sensitivity analysis for the pooled hazard ratios in all patients with gastrointestinal tumors. The analysis was conducted by estimating the average hazard ratio in the absence of each study.

Additional file 6: Figure S6. Forest plot showing the meta-analysis of hazard ratio estimates for DFS/PFS in all patients. DFS, disease-free survival; PFS, progression-free survival.

Additional file 7: Table S1. Results of meta-regression analyses exploring causes of heterogeneity with DFS/PFS in solid tumors.

Additional file 8: Figure S7. Forest plots of the association between YKL-40 and clinicopathological parameters. (a)tumor stage (III-IVVs.I-II, C-D vs. A-B or extended vs. limited). Experimental, stage(III-IV, C-D or extended); Control, (I-II, A-B or limited). (b)metastasis status(lymph node or liver metastasis vs. no metastasis). Experimental, lymph node or liver metastasis. Control, no metastasis.

\section{Abbreviations}

HR: hazard ratio; Cls: confidence intervals; OS: overall survival; TNM: tumornode-metastasis; hCGP-39: human cartilage glycoprotein-39; CHI3L1: chitinase-3-like-1 protein; mAY: monoclonal anti-YKL-40 antibody; IR: irradiation; DFS: disease-free survival; PFS: progression-free survival; NOS: NewcastleOttawa Scale; OR: odds ratio.

\section{Acknowledgements}

We would like to thank all researchers for their contributions.

\section{Authors' contributions}

Conceived and designed the experiments: LSS. Performed the experiments: $B X B, L L$. Analyzed the data: BXB, LL, JYY, YL, GHX, YXZ, LZ, JXZ. Contributed reagents/materials/analysis tools: BXB, LL, JYY, YL, GHX, YXZ, LZ, JXZ. Wrote the paper: BXB, LL. All authors read and approved the final manuscript.

\section{Funding}

The work was supported by the National Natural Science Foundation of China (Grant Numbers 81372641, 81672363, 81571525, 81873863 and 81802082) to Lisong Shen, Yingxia Zheng and Junyao Yang.

\section{Availability of data and materials}

All relevant data are within the paper and its additional information files.

\section{Ethics approval and consent to participate}

The meta-analysis was based on previous published studies. Therefore, no ethical approval is required.

\section{Consent for publication}

Not applicable.

\section{Competing interests}

The authors declare that they have no competing interests.

\section{Author details}

${ }^{1}$ Department of Clinical Laboratory, Xin Hua Hospital, Shanghai Jiao Tong University School of Medicine, Shanghai, China. ${ }^{2}$ Department of Engineering, Tsinghua University, Beijing, China.

Received: 2 July 2019 Accepted: 27 September 2019

Published online: 10 October 2019

\section{References}

1. Bray F, Ferlay J, Soerjomataram I, Siegel RL, Torre LA, Jemal A. Global Cancer Statistics 2018: GLOBOCAN estimates of incidence and mortality worldwide for 36 cancers in 185 countries. CA Cancer J Clin 2018;68(6):394-424

2. Hakala BE, White $C$, Recklies AD. Human cartilage gp-39, a major secretory product of articular chondrocytes and synovial cells, is a mammalian member of a chitinase protein family. J Biol Chem. 1993:268(34):25803-10.

3. Lee CG, Hartl D, Lee GR, Koller B, Matsuura H, Da Silva CA, et al. Role of breast regression protein 39 (BRP-39)/chitinase 3-like-1 in Th2 and IL-13-induced tissue responses and apoptosis. J Exp Med. 2009:206(5):1149-66.

4. Kawada M, Seno H, Kanda K, Nakanishi Y, Akitake R, Komekado H, et al. Chitinase 3-like 1 promotes macrophage recruitment and angiogenesis in colorectal cancer. Oncogene. 2012;31(26):3111-23.

5. Ku BM, Lee YK, Ryu J, Jeong JY, Choi J, Eun KM, et al. CHI3L1(YKL-40) is expressed in human gliomas and regulates the invasion, growth and survival of glioma cells. Int J Cancer. 2011;128(6):1316-26.

6. Lee CG, Da Silva CA, Dela Cruz CS, Ahangari F, Ma B, Kang MJ, et al. Role of chitin and chitinase/chitinase-like proteins in inflammation, tissue remodeling, and injury. Annu Rev Physiol. 2011;73:479-501.

7. Faibish M, Francescone R, Bentley B, Yan W, Shao R. A YKL-40-neutralizing antibody blocks tumor angiogenesis and progression: a potential therapeutic agent in cancers. Mol Cancer Ther. 2011;10(5):742-51.

8. Shao R, Francescone R, Ngernyuang N, Bentley B, Taylor SL, Moral L, et al. Anti-YKL-40 antibody and ionizing irradiation synergistically inhibit tumor vascularization and malignancy in glioblastoma. Carcinogenesis. 2014;35(2):373-82.

9. Johansen JS, Cintin C, Jørgensen M, Kamby C, Price PA. Serum YKL-40: a new potential marker of prognosis and location of metastases of patients with recurrent breast cancer. Eur J Cancer. 1995;31A(9):1437-42.

10. Qin G, Li X, Chen Z, Liao G, Su Y, Chen Y, et al. Prognostic value of YKL-40 in patients with glioblastoma: a systematic review and meta-analysis. Mol Neurobiol. 2017:54(5):3264-70.

11. Wan G, Xiang L, Sun X, Wang X, Li H, Ge W, et al. Elevated YKL-40 expression is associated with a poor prognosis in breast cancer patients. Oncotarget. 2017;8(3):5382-91.

12. Parmar MK, Torri V, Stewart L. Extracting summary statistics to perform meta-analyses of the published literature for survival endpoints. Stat Med. 1998:17(24):2815-34

13. Mantel N, Haenszel W. Statistical aspects of the analysis of data from retrospective studies of disease. J Natl Cancer Inst. 1959:22(4):719-48.

14. DerSimonian R, Laird N. Meta-analysis in clinical trials. Control Clin Trials. 1986;7(3):177-88

15. Begg CB, Mazumdar M. Operating characteristics of a rank correlation test for publication bias. Biometrics. 1994;50(4):1088-101.

16. Egger M, Davey Smith G, Schneider M, Minder C. Bias in meta-analysis detected by a simple, graphical test. BMJ. 1997;315(7109):629-34.

17. Duval S, Tweedie R. Trim and fill: a simple funnel-plot-based method of testing and adjusting for publication bias in meta-analysis. Biometrics. 2000;56(2):455-63.

18. Cintin C, Johansen JS, Christensen IJ, Price PA, Sørensen S, Nielsen HJ. Serum YKL-40 and colorectal cancer. Br J Cancer. 1999;79(9-10):1494-9.

19. Dehn H, Høgdall EV, Johansen JS, Jørgensen M, Price PA, Engelholm SA, et al. Plasma YKL-40, as a prognostic tumor marker in recurrent ovarian cancer. Acta Obstet Gynecol Scand. 2003;82(3):287-93. 
20. Høgdall EV, Johansen JS, Kjaer SK, Price PA, Christensen L, Blaakaer J, et al. High plasma YKL-40 level in patients with ovarian cancer stage III is related to shorter survival. Oncol Rep. 2003;10(5):1535-8.

21. Jensen BV, Johansen JS, Price PA. High levels of serum HER-2/neu and YKL-40 independently reflect aggressiveness of metastatic breast cancer. Clin Cancer Res. 2003;9(12):4423-34.

22. Johansen JS, Christensen IJ, Riisbro R, Greenall M, Han C, Price PA, et al. High serum YKL-40 levels in patients with primary breast cancer is related to short recurrence free survival. Breast Cancer Res Treat. 2003;80(1):15-21.

23. Johansen JS, Drivsholm L, Price PA, Christensen IJ. High serum YKL-40 level in patients with small cell lung cancer is related to early death. Lung Cancer. 2004:46(3):333-40.

24. Brasso K, Christensen IJ, Johansen JS, Teisner B, Garnero P, Price PA, et al. Prognostic value of PINP, bone alkaline phosphatase, CTX-I, and YKL-40 in patients with metastatic prostate carcinoma. Prostate. 2006;66(5):503-13.

25. Schmidt H, Johansen JS, Sjoegren P, Christensen IJ, Sorensen BS, Fode K, et al. Serum YKL-40 predicts relapse-free and overall survival in patients with American Joint Committee on Cancer stage I and II melanoma. J Clin Oncol. 2006;24(5):798-804.

26. Schmidt H, Johansen JS, Gehl J, Geertsen PF, Fode K, von der Maase H. Elevated serum level of YKL-40 is an independent prognostic factor for poor survival in patients with metastatic melanoma. Cancer. 2006;106(5):1130-9.

27. Johansen JS, Brasso K, Iversen P, Teisner B, Garnero P, Price PA, et al. Changes of biochemical markers of bone turnover and YKL-40 following hormonal treatment for metastatic prostate cancer are related to survival. Clin Cancer Res. 2007;13(11):3244-9.

28. Roslind A, Johansen JS, Christensen IJ, Kiss K, Balslev E, Nielsen DL, et al. High serum levels of YKL-40 in patients with squamous cell carcinoma of the head and neck are associated with short survival. Int J Cancer. 2008;122(4):857-63.

29. Yamac D, Ozturk B, Coskun U, Tekin E, Sancak B, Yildiz R, et al. Serum YKL40 levels as a prognostic factor in patients with locally advanced breast cancer. Adv Ther. 2008:25(8):801-9.

30. Chang ST, Zahn JM, Horecka J, Kunz PL, Ford JM, Fisher GA, et al. Identification of a biomarker panel using a multiplex proximity ligation assay improves accuracy of pancreatic cancer diagnosis. J Transl Med. 2009; 7:105.

31. Høgdall EV, Ringsholt M, Høgdall CK, Christensen IJ, Johansen JS, Kjaer SK, et al. YKL-40 tissue expression and plasma levels in patients with ovarian cancer. BMC Cancer. 2009:9:8.

32. Johansen JS, Bojesen SE, Mylin AK, Frikke-Schmidt R, Price PA, Nordestgaard BG. Elevated plasma YKL-40 predicts increased risk of gastrointestinal cancer and decreased survival after any cancer diagnosis in the general population. J Clin Oncol. 2009;27(4):572-8.

33. Mitsuhashi A, Matsui H, Usui H, Nagai Y, Tate S, Unno Y, et al. Serum YKL-40 as a marker for cervical adenocarcinoma. Ann Oncol. 2009;20(1):71-7.

34. Choi IK, Kim YH, Kim JS, Seo JH. High serum YKL-40 is a poor prognostic marker in patients with advanced non-small cell lung cancer. Acta Oncol. 2010:49(6):861-4

35. Thöm I, Andritzky B, Schuch G, Burkholder I, Edler L, Johansen JS, et al. Elevated pretreatment serum concentration of YKL-40-An independent prognostic biomarker for poor survival in patients with metastatic nonsmall cell lung cancer. Cancer. 2010;116(17):4114-21.

36. Iwamoto FM, Hottinger AF, Karimi S, Riedel E, Dantis J, Jahdi M, et al. Serum YKL-40 is a marker of prognosis and disease status in high-grade gliomas. Neuro Oncol. 2011;13(11):1244-51.

37. Bernardi D, Padoan A, Ballin A, Sartori M, Manara R, Scienza R, et al. Serum YKL-40 following resection for cerebral glioblastoma. J Neurooncol. 2012;107(2):299-305.

38. Wang D, Zhai B, Hu F, Liu C, Zhao J, Xu J. High YKL-40 serum concentration is correlated with prognosis of Chinese patients with breast cancer. PLoS ONE. 2012;7(12):e51127.

39. Zhu CB, Wang C, Chen LL, Ma GL, Zhang SC, Su L, et al. Serum YKL-40 independently predicts outcome after transcatheter arterial chemoembolization of hepatocellular carcinoma. PLoS ONE. 2012;7(9):e44648.

40. Zhu CB, Chen LL, Tian JJ, Su L, Wang C, Gai ZT, et al. Elevated serum YKL-40 level predicts poor prognosis in hepatocellular carcinoma after surgery. Ann Surg Oncol. 2012;19(3):817-25.
41. Schultz NA, Christensen IJ, Werner J, Giese N, Jensen BV, Larsen O, et al. Diagnostic and Prognostic impact of circulating YKL-40, IL-6, and CA 19.9 in patients with pancreatic cancer. PLoS ONE. 2013;8(6):e67059.

42. Gállego Pérez-Larraya J, Paris S, Idbaih A, Dehais C, Laigle-Donadey F, Navarro $\mathrm{S}$, et al. Diagnostic and prognostic value of preoperative combined GFAP, IGFBP-2, and YKL-40 plasma levels in patients with glioblastoma. Cancer. 2014;120(24):3972-80

43. Liu X, Zhang Y, Zhu Z, Ha M, Wang Y. Elevated pretreatment serum concentration of YKL-40: an independent prognostic biomarker for poor survival in patients with colorectal cancer. Med Oncol. 2014;31(8):85.

44. Tarpgaard LS, Guren TK, Glimelius B, Christensen IJ, Pfeiffer P, Kure EH, et al. Plasma YKL-40 in patients with metastatic colorectal cancer treated with first line oxaliplatin-based regimen with or without cetuximab: RESULTS from the NORDIC VII Study. PLoS ONE. 2014;9(2):e87746.

45. Tschirdewahn S, Reis H, Niedworok C, Nyirady P, Szendröi A, Schmid $\mathrm{KW}$, et al. Prognostic effect of serum and tissue YKL-40 levels in bladder cancer. Urol Oncol. 2014;32(5):663-9.

46. $\mathrm{Xu} \mathrm{CH}$, Yu LK, Hao KK. Serum YKL-40 level is associated with the chemotherapy response and prognosis of patients with small cell lung cancer. PLOS ONE. 2014:9(5):e96384.

47. Jensen BV, Spindler KLG, Christensen IJ, Schou JV, Nielsen DL, Jakobsen A, Høgdall E, Pfeiffer P, Yilmaz MK, Johansen J. Plasma YKL-40 as a biomarker for poor prognosis in patients with metastatic colorectal cancer treated with 3. line cetuximab and irinotecan. Ann Oncol. 2016; 27(Supplement $6)$.

48. Vom Dorp F, Tschirdewahn S, Niedworok C, Reis H, Krause H, Kempkensteffen C, et al. Circulating and tissue expression levels of YKL-40 in renal cell cancer. J Urol. 2016;195(4 Pt 1):1120-5.

49. Boisen MK, Madsen CV, Dehlendorff C, Jakobsen A, Johansen JS, Steffensen KD. The prognostic value of plasma YKL-40 in patients with chemotherapy-resistant ovarian cancer treated with bevacizumab. Int J Gynecol Cancer. 2016;26(8):1390-8.

50. Thongsom S, Chaocharoen W, Silsirivanit A, Wongkham S, Sripa B, Choe H, et al. YKL-40/chitinase-3-like protein 1 is associated with poor prognosis and promotes cell growth and migration of cholangiocarcinoma. Tumour Biol. 2016;37(7):9451-63.

51. Krogh M, Christensen I, Bouwhuis M, Johansen JS, Nørgaard P, Schmidt H, et al. Prognostic and predictive value of YKL-40 in stage IIB-III melanoma. Melanoma Res. 2016;26(4):367-76.

52. Gramkow MH, Peltonen R, Dehlendorff C, Osterlund PJ, Johansen JS, Isoniemi $\mathrm{H}$. The prognostic value of serum IL-6 and YKL-40 in colorectal cancer patients before liver resection. J Clin Oncol. 2017;35(15 Supplement):1.

53. Erturk K, Tas F, Serilmez M, Bilgin E, Yasasever V. Clinical significance of serum Ykl-40 (Chitinase-3-Like-1 Protein) as a biomarker in melanoma: an analysis of 112 Turkish patients. Asian Pac J Cancer Prev. 2017:18(5):1383-7.

54. Väänänen T, Kallio J, Vuolteenaho K, Ojala A, Luukkaala T, Hämäläinen $M$, et al. High YKL-40 is associated with poor survival in patients with renal cell carcinoma: a novel independent prognostic marker. Scand J Urol. 2017:51(5):367-72.

55. Fuksiewicz M, Kotowicz B, Rutkowski A, Achinger-Kawecka J, Wagrodzki $\mathrm{M}$, Kowalska MM. The assessment of clinical usage and prognostic value of YKL-40 serum levels in patients with rectal cancer without distant metastasis. Technol Cancer Res Treat. 2018;17:1533033818765209.

56. Darr C, Krafft U, Hadaschik B, Tschirdewahn S, Sevcenco S, Csizmarik A, et al. The role of YKL-40 in predicting resistance to docetaxel chemotherapy in prostate cancer. Urol Int. 2018;101(1):65-73.

57. Matsuo N, Azuma K, Hattori S, Ohtake J, Kawahara A, Ishii H, et al. Association between soluble immune mediators and tumor responses in patients with nonsmall cell lung cancer treated with anti-PD-1 inhibitor. Int J Cancer. 2019;144(5):1170-9.

58. Jeet $\mathrm{V}$, Tevz G, Lehman M, Hollier B, Nelson C. Elevated YKL40 is associated with advanced prostate cancer (PCa) and positively regulates invasion and migration of PCa cells. Endocr Relat Cancer. 2014;21(5):723-37.

59. Pelloski CE, Ballman KV, Furth AF, Zhang L, Lin E, Sulman EP, et al. Epidermal growth factor receptor variant III status defines clinically distinct subtypes of glioblastoma. J Clin Oncol. 2007;25(16):2288-94. 
60. Pelloski CE, Mahajan A, Maor M, Chang EL, Woo S, Gilbert M, et al. YKL-40 expression is associated with poorer response to radiation and shorter overall survival in glioblastoma. Clin Cancer Res. 2005;11(9):3326-34.

61. Shao R, Cao QJ, Arenas RB, Bigelow C, Bentley B, Yan W. Breast cancer expression of YKL-40 correlates with tumour grade, poor differentiation, and other cancer markers. Br J Cancer. 2011;105(8):1203-9.

62. Kang EJ, Jung H, Woo OH, Park KH, Woo SU, Yang DS, et al. YKL-40 expression could be a poor prognostic marker in the breast cancer tissue. Tumour Biol. 2014:35(1):277-86.
63. Bojesen SE, Johansen JS, Nordestgaard BG. Plasma YKL-40 levels in healthy subjects from the general population. Clin Chim Acta. 2011:412(9-10):709-12.

\section{Publisher's Note}

Springer Nature remains neutral with regard to jurisdictional claims in published maps and institutional affiliations.
Ready to submit your research? Choose BMC and benefit from:

- fast, convenient online submission

- thorough peer review by experienced researchers in your field

- rapid publication on acceptance

- support for research data, including large and complex data types

- gold Open Access which fosters wider collaboration and increased citations

- maximum visibility for your research: over $100 \mathrm{M}$ website views per year

At BMC, research is always in progress.

Learn more biomedcentral.com/submissions 